\title{
Biomass Smoke and Rural Health: Indian Women are at Risk
}

\section{Nandan Kumar Mondal*}

Department of Cardiovascular and Thoracic Surgery, Cardiovascular Innovation Institute, University of Louisville, 302 E. Muhammad Ali Blvd, Louisville KY 40202, USA

\section{Editorial}

About half of the world's population, mostly in rural areas of Asia, Sub-Saharan Africa and Latin America, still rely on unprocessed biomass as their primary source of domestic energy. Nearly 2 billion $\mathrm{kg}$ of biomass such as wood, animal dung and agricultural wastes are burned everyday in developing countries, and it accounts for more than $80 \%$ of domestic energy in India. A survey conducted jointly by National Council of Applied Economic Research and World Bank in 1996 has reported that about 578 million tons of biomass is used annually in India as a source of domestic energy of which wood constitutes $52 \%$, animal dung $21 \%$ and agricultural refuse $20 \%$. The annual consumption of wood is 302.1 million tons, dung cake 120.6 million tons and crop residues 115 million tons. In general, rural domestic sector in India uses 1.2-2.1 kg of biomass/capita/day [1].

In West Bengal, a state of eastern India, 45.6 million tons of biomass is used annually for cooking and room heating. Firewood remains the mainstay of biomass fuel in the state with an annual usage of 23.3 million tons/year, followed by agricultural wastes (11.9 million tons/ year) and dung cakes (10.3 million tons/year). Biomass fuel use as a source of domestic energy is even more in Bangladesh and Nepal where $88 \%$ and $80 \%$ of the population respectively are dependent on biomass fuels for household cooking. The percentage of users is marginally lower in Pakistan (72\%) and Sri Lanka (67\%) [2].

Poverty is the major cause of biomass fuel use. People living in rural areas of developing countries are generally poor who can ill afford cleaner fuel such as liquefied petroleum gas (LPG) with their modest income. Instead, they rely on biomass which are cheaper (or free of cost) and readily available. No wonder, there are only a handful of LPG users in rural India, and in most of the cases the LPG owners also use biomass (mixed user) to reduce fuel cost.

Biomass fuels are at the high end of the fuel ladder in terms of pollution emissions, and at the low end in terms of combustion efficiency. Biomass burning during daily household cooking usually in un-vented kitchen emits very high levels of smoke that contains a wide range of potentially hazardous pollutants. They include particulates; carbon monoxide (CO); oxides of nitrogen and sulfur; polycyclic aromatic hydrocarbons including carcinogens such as benzo(a)pyrene (PAHs), volatile organic compounds (VOCs) including benzene, a human leukemogen and trace metals including $\mathrm{Fe}, \mathrm{Cu}, \mathrm{Ni}, \mathrm{Cr}$ and $\mathrm{Pb}$ [3-5].

Airborne particles with a diameter of less than $10 \mu \mathrm{m}\left(\mathrm{PM}_{10}\right)$ are hazardous because they can be inhaled deep inside the lungs and serve as a vehicle for toxic matters that usually adsorb onto their surface. Burning biomass emits more $\mathrm{PM}_{10}$ than LPG or electricity. For example, particle concentrations in the kitchen vary from 200 to 5,000 $\mu \mathrm{g} / \mathrm{m}^{3}$ of air during cooking with biomass fuels [6,7] in contrast to 200-380 $\mu \mathrm{g} / \mathrm{m}^{3}$ during cooking with LPG or electricity [8]. Moreover, fine (aerodynamic diameter $<2.5 \mu \mathrm{m}, \mathrm{PM}_{2.5}$ ) and ultrafine particles (diameter $<0.1 \mu \mathrm{m}$ ), constitute a bulk of the biomass smoke [9] and most of the mass is due to the presence of fine particles i.e. $\mathrm{PM}_{25}$ which are more harmful for human health than $\mathrm{PM}_{10}$ [10]. Biomass smoke is considered even more harmful than diesel, because it contains 10-times more mass concentration of respirable particles having diameter of 0.5 $0.8 \mu \mathrm{m}$ compared to diesel [11].

In rural India, the biomass-using ovens are not vented outside, kitchens are often poorly ventilated, and half of the poor, rural families do not have separate kitchen. These factors contribute significantly to high particulate level in cooking areas. A typical biomass-using Indian kitchen, the 24-hr average concentration of $\mathrm{PM}_{10}$ ranged from 500$2000 \mu \mathrm{g} / \mathrm{m}^{3}$ during cooking [12] and the level of IAP depends on the type of fuel, stove and housing [6,7]. This implies that women who used to cook with biomass are inhaling approximately about $23,000 \mu \mathrm{g}(23.0$ $\mathrm{mg}$ ) of $\mathrm{PM}_{10}$ per day, quite in contrast to a normal baseline of 1,728 $\mu \mathrm{g}(1.7 \mathrm{mg})$ per day. This is highly significant from health perspective because for every $20 \mu \mathrm{g} / \mathrm{m}^{3}$ of $\mathrm{PM}_{10}$ rise in ambient air, daily mortality increases by $1 \%$.

Indoor air pollution (IAP) also varies with type of biomass used for cooking or room heating. Compared with wood, combustion of dung cakes and briquette emitted significantly higher carbon monoxide and particulate matter. Exposure to this high pollution load from burning biomass fuels is regarded as one of the most important environmental and public health problems in developing countries especially in women who cook with these fuels and in young children who attend to the fires or stay close to their mothers during cooking. It has been estimated that IAP from biomass use in developing countries is responsible for 4-5 percent of global burden of disease for both deaths and DALYs (disability adjusted lost life years) from acute respiratory infections (ARI), chronic obstructive pulmonary disease (COPD), tuberculosis, asthma, genetic damage $[13,14]$ lung cancer [15], ischemic heart disease and blindness. India registers over 600,000 premature deaths per year due to biomass fuel combustion. Smoke inhalation has been reported to be an important cause of acute lung injury with high mortality rate. Increasing evidence suggests that screening and early detection may improve the outcome of lung cancer.

\section{References}

1. Smith KR (1987) Biofuels, air pollution, and health. A global review. Plenum Press, New York, 1987.

2. World Health Organization (2006) Fuels for life: Household Energy and Health Rehfuess E, WHO Library Cataloguing-in-Publication Data.

3. Zhang J, Smith KR (1996) Hydrocarbon emissions and health risks from cook stoves in developing countries. J Exp Anal Environ Epidemiol 6: 147-161.

4. Bruce N, Perez-Padilla R, Albalak R (2000) Indoor air pollution in developing

*Corresponding author: Nandan Kumar Mondal, Department of Cardiovascular and Thoracic Surgery, Cardiovascular Innovation Institute, University of Louisville, 302 E. Muhammad Ali Blvd, Louisville KY 40202, USA, Tel: +1 502-852-5555; E-mail: nandan_gm@yahoo.com

Received December 17, 2014; Accepted December 19, 2014; Published December 21, 2014

Citation: Mondal NK (2014) Biomass Smoke and Rural Health: Indian Women are at Risk. J Biosafety Health Educ 2: e116. doi:10.4172/2332-0893.1000e116

Copyright: @ 2014 Mondal NK. This is an open-access article distributed under the terms of the Creative Commons Attribution License, which permits unrestricted use, distribution, and reproduction in any medium, provided the original author and source are credited. 
Citation: Mondal NK (2014) Biomass Smoke and Rural Health: Indian Women are at Risk. J Biosafety Health Educ 2: e116. doi:10.4172/2332$0893.1000 \mathrm{e} 116$

countries: a major environmental and public health challenge for the new millennium. Bull World Health Org 78: 1078-1092.

5. Smith KR (2000) National Burden of Disease in India from Indoor Air Pollution. Proc Natl Acad Sci 97: 13286-13293.

6. Smith KR (1993) Fuel combustion, air pollution exposure, and health: situation in developing countries, Annu Rev Energy Environ 18: 529-566.

7. Ezzati M, Kammen DM (2002) The health impacts of exposure to indoor air pollution from solid fuels in developing countries: Knowledge, gaps, and data needs. Environ Health Perspect 110: 1057- 1068.

8. Ellegard A (1996) Cooking smoke and respiratory symptoms among women in low-income areas of Maputo. Environ Health Perspect 104: 980-985.

9. Tesfaigzi Y, Singh SP, Foster JE, Kubatko J, Barr EB, et al. (2002) Health effects of sub chronic exposure to low levels of wood smoke in the rats. Toxicol Sci 65: 115-125.

10. World Health Organization (1999) Guidelines for Air Quality. WHO Publications, Geneva, Switzerland, 1999
11. Venkataraman C, Rao GU (2001) Emission factors of CO and size-resolved aerosols from biofuel combustion. Environ Sci Technol 35: 2100.

12. Balakrishnan K, Sankar S, Parikh J, Padmavati R, Srividya K, et al. (2002) Daily average exposures to respirable particulate matter from combustion of biomass fuels in rural households of southern India. Environ Health Perspec 110: 1069-1075

13. Mondal NK, Bhattacharya P, Ray MR (2011) Assessment of DNA damage by comet assay and fast halo assay in buccal epithelial cells of Indian women chronically exposed to biomass smoke. Int J Hyg Environ Health 214: 311-318.

14. Mondal NK, Mukherjee B, Das D, Ray MR (2010) Micronucleus formation, DNA damage and repair in premenopausal women chronically exposed to high leve of indoor air pollution from biomass fuel use in rural India. Mutat Res 697: 4754.

15. Roychoudhury S, Mondal NK, Mukherjee S, Dutta A, Siddique S, et al. (2012) Activation of protein kinase $B$ (PKB/Akt) and risk of lung cancer among rura women in India who cook with biomass fuel. Toxicol Appl Pharmacol 259: 4553. 